\title{
Pengaruh Due Professional Care, Kompleksitas Audit, dan Integritas Auditor terhadap Kualitas Audit pada Kantor Akuntan Publik di Medan
}

\author{
Yenny ${ }^{1}$ \\ Universitas Prima Indonesia \\ yennysuwantoo@gmail.com \\ Sherine $^{3}$ \\ Universitas Prima Indonesia \\ sherinexie05@gmail.com
Wilsa Road Betterment Sitepu ${ }^{5}$
Universitas Prima Indonesia
will_better_sitepu@yahoo.co.id

\author{
Verawati $^{2}$ \\ Universitas Prima Indonesia \\ watyv80@gmail.com \\ Devy Mestika ${ }^{4}$ \\ Universitas Prima Indonesia \\ mestikadevy@gmail.com \\ Rika Dinarianti ${ }^{6}$ \\ Universitas Prima Indonesia \\ rika_dinarianti@yahoo.com
}

\begin{abstract}
Abstrak
Kantor Akuntan Publik sangat dibutuhkan di Indonesia, untuk memenuhi kepentingan para pengguna atas kewajaran informasi keuangan maka dibutuhkan Kantor Akuntan Publik. Oleh karena itu, peneliti tertarik untuk menjadikan Kantor Akuntan Publik sebagai objek penelitian. Penelitian ini dilakukan untuk mengetahui pengaruh Due Professional Care, Kompleksitas Audit, dan Integritas Auditor terhadap Kualitas Audit pada Kantor Akuntan Publik di Medan. Penelitian ini menggunakan data primer berupa jawaban-jawaban responden dari pengumpulan hasil data kuesioner. Penelitian ini menggunakan metode sampling purposive dalam penentuan sampel dan terdapat total populasi 90 auditor yang terdiri dari 60 auditor yang dijadikan sampel penelitian. Penelitian ini menggunakan analisis regresi linear berganda. Hasil dari penelitian ini memberikan bukti secara empiris bahwa Due Professional Care dan Integritas Auditor berpengaruh signifikan dan positif terhadap Kualitas Audit, sedangkan Kompleksitas Audit berpengaruh signifikan dan negatif terhadap Kualitas Audit.
\end{abstract}

Kata Kunci : Due Professional Care, Kompleksitas Audit, Integritas Auditor, Kualitas Audit

\section{PENDAHULUAN}

\subsection{Latar Belakang}

Pengetahuan dan teknologi informasi telah berkembang pesat sehingga menyadarkan para masyarakat terutama para pengusaha bahwa pentingnya informasi dalam suatu perusahaan. Para manajemen perusahaan selalu memberikan laporan pertanggungjawaban berupa laporan keuangan yang digunakan untuk para pemegang saham, 
investor, dan para kreditur. Informasi yang terdapat didalam laporan keuangan tersebut bertujuan untuk memberikan kemudahan bagi para investor dan kreditur untuk menilai laporan keuangan suatu perusahaan tersebut. Namun bagi para investor dan kreditur, laporan keuangan yang disajikan oleh manajemen perusahaan kemungkinan mengandung kepentingan pribadi dan ketidakjujuran dalam menyajikan laporan keuangan.

Setiap perusahaan harus melakukan pemeriksaan atas laporan keuangannya untuk mendapatkan informasi yang lebih akurat, maka dibutuhkan jasa akuntan publik untuk memberikan jaminan bahwa laporan keuangan tersebut telah relevan dan andal. Jasa dari Akuntan Publik itu haruslah bersifat independen dan objektif.

Kualitas audit sangat dibutuhkan dalam diri seorang auditor karena kualitas menggambarkan bagaimana cara kerja seorang auditor dalam membantu menyelesaikan suatu masalah klien, dan membantu klien dalam mengaudit suatu laporan keuangan perusahaan. Auditor diharapkan dapat melaksanakan tugasnya dengan sebaik-baiknya untuk menghindari kecurangan dan kesengajaan dalam memanipulasi suatu data. Sebaliknya, jika seorang auditor melakukan kecurangan tersebut maka kualitas auditnya sebagai seorang auditor akan menurun.

Salah satu faktor penting yang mempengaruhi kualitas audit adalah due professional care. Penggunaan kemahiran profesional dengan cermat dan seksama itu penting dalam diri seorang auditor, karena seorang auditor harus selalu melakukan evaluasi terhadap bukti auditnya sehingga laporan keuangan yang dihasilkan tersebut tidak salah saji. Penerapan due professional care itu sangatlah penting bagi para akuntan publik, agar tercapainya kualitas audit yang memadai.

Penelitian sebelumnya dilakukan oleh Pancawati Hardianingsih dan Rachmawati Meita Oktaviani (2012) membuktikan bahwa due professional care berpengaruh positif terhadap kualitas audit. Hasil ini menunjukkan bahwa setiap auditor selalu selalu melakukan review secara kritis pada setiap tingkat supervisi terhadap pelaksanaan audit dan terhadap setiap pertimbangan audit maka auditor akan selalu menjaga kualitas hasil auditnya.

Auditor selalu dihadapkan dengan tugas-tugas yang sulit, banyak, berbeda-beda, dan saling berkaitan satu sama lain. Hal ini terjadi karena audit akan menjadi semakin kompleks jika tingkat kesulitan semakin tinggi. Tugas yang semakin kompleks dapat dijadikan tantangan tersendiri bagi seorang auditor untuk tetap mampu menjaga dan mempertahankan kualitas audit.

Penelitian sebelumnya yang dilakukan Prasita dan Adi (2007) membuktikan bahwa kompleksitas audit berpengaruh negatif terhadap kualitas audit. Hasil ini menunjukkan bahwa kompleksitas audit yang muncul karena semakin tingginya variabilitas dan ambiguitas tugas pengauditan menjadi indikasi penyebab turunnya kualitas audit. Dalam situasi seperti itu, auditor cenderung berperilaku disfungsional 
dan lebih mengutamakan kepentingan klien daripada obyektivitas hasil pengauditan itu sendiri.

Auditor juga dituntut untuk bersikap jujur, berani, bijaksana dan bertanggung jawab dalam melakukan tugasnya sehingga dapat menimbulkan rasa kepercayaan dalam diri masyarakat bahwa auditor selalu melakukan tugasnya secara jujur dan bertanggung jawab. Sikap ini juga harus ada didalam diri seorang auditor, karena sikap inilah yang paling penting dan sulit untuk diterapkan yaitu mengutamakan kejujuran, bertindak adil, dan tidak memihak suatu pihak tertentu. Integritas sangat berpengaruh terhadap kualitas audit, karena jika seorang auditor tidak dapat menerapkan sikap integritas dalam dirinya berarti auditor tersebut telah menurunkan kualitas auditnya.

Hasil penelitian Yenny (2012) membuktikan bahwa integritas auditor berpengaruh positif terhadap kualitas audit. Hal ini menunjukkan bahwa jika seorang auditor memiliki sikap jujur, berani, bijaksana dan bertanggung jawab dalam melaksanakan audit maka dapat membangun kepercayaan dan memberikan dasar bagi pengambilan keputusan yang handal.

Kasus yang terjadi pada Kantor Akuntan Publik di Medan yaitu sanksi beku dan sanksi cabut izin pada Kantor Akuntan Publik Biasa Sitepu. Kantor Akuntan Publik Biasa Sitepu juga belum sepenuhnya mematuhi Standar Audit dan Standar Profesional Akuntan Publik dalam pelaksanaan audit PT Jui Shin Indonesia tahun buku 2016. Laporan
Keuangan PT Jui Shin Indonesia belum melakukan pengujian saldo awal dan juga tidak memiliki bukti audit yang cukup dan tepat dalam meyakini kewajaran saldo akun Penjualan, Piutang Usaha, Utang Usaha, Aset Tetap, Persediaan, dan Harga Pokok Penjualan. (www.iapi.co.id)

Berdasarkan contoh kasus diatas, dapat dijelaskan masih banyak pelanggaran-pelanggaran yang dilakukan oleh auditor. Pelanggaran tersebut akan mempengaruhi persepsi masyarakat terhadap profesi akuntan dimana nantinya akan berefek pada turunnya kepercayaan publik terhadap profesi akuntan publik. Ada 3 komponen yang harus wajib dimiliki oleh seorang auditor yaitu kemampuan untuk menemukan salah saji dalam laporan keuangan tersebut tergantung pada kecermatan auditor, kemampuan untuk menghadapi kompleksitas audit tergantung pada keahlian auditor dalam menghadapi tugas yang kompleks, serta adanya kemauan untuk melaporkan suatu temuan yang salah saji tergantung pada integritasnya dan sikap tanggung jawab auditor sangat penting dalam menghasilkan audit yang berkualitas.

Berdasarkan uraian tersebut, maka peneliti tertarik melakukan penelitian dengan judul "Pengaruh Due Professional Care, Kompleksitas Audit, dan Integritas Auditor Terhadap Kualitas Audit Pada Kantor Akuntan Publik di Medan”.

\subsection{Perumusan Masalah}

Berdasarkan latar belakang masalah dan identifikasi masalah di 
atas, maka dapat dirumuskan permasalahan yang ada sebagai berikut :

1. Bagaimana pengaruh Due Professional Care terhadap Kualitas Audit pada Kantor Akuntan Publik di Medan?

2. Bagaimana pengaruh Kompleksitas Audit terhadap Kualitas Audit pada Kantor Akuntan Publik di Medan?

3. Bagaimana pengaruh Integritas Auditor terhadap Kualitas Audit pada Kantor Akuntan Publik di Medan?

4. Bagaimana pengaruh Due Professional Care, Kompleksitas Audit, dan Integritas Auditor terhadap Kualitas Audit pada Kantor Akuntan Publik di Medan?

\subsection{Tujuan Penelitian}

Berdasarkan perumusan masalah di atas, maka tujuan penelitian ini adalah:

1. Untuk menguji dan menganalisis pengaruh Due Professional Care terhadap Kualitas Audit pada Kantor Akuntan Publik di Medan.

2. Untuk menguji dan menganalisis pengaruh Kompleksitas Audit terhadap Kualitas Audit pada Kantor Akuntan Publik di Medan.

3. Untuk menguji dan menganalisis pengaruh Integritas Auditor terhadap Kualitas Audit pada Kantor Akuntan Publik di Medan.

4. Untuk menguji dan menganalisis pengaruh Due Professional Care, Kompleksitas Audit, dan Integritas Auditor terhadap Kualitas Audit pada Kantor Akuntan Publik di Medan.

\section{LANDASAN TEORI}

\subsection{Due Professional Care}

Menurut Rahayu (2010:42), due professional care merupakan penggunaan kemahiran profesional dengan cermat dan seksama menekankan tanggung jawab kepada setiap profesional yang bekerja dalam organisasi auditor independen untuk mengamati standar pekerjaan lapangan dan standar pelaporan.

Menurut Tuanakotta (2011:59), due audit care yang berarti due care dalam audit. Due audit care atau kehati-hatian dalam melakukan suatu audit ada ukurannya, yakni kode etik dan standar audit.

Menurut Aulia (2013) ada lima indikator yang dapat digunakan untuk mengukur due professional care antara lain:

1. Menggunakan kecermatan dan keterampilan dalam bekerja

2. Memiliki keteguhan dalam melaksanakan tanggungjawab

3. Kompeten dan berhati-hati dalam melaksanakan tugas

4. Adanya kemungkinan terjadi kesalahan, ketidakteraturan dan ketidakpatuhan

5. Waspada pada resiko yang signifikan yang dapat mempengaruhi objektivitas

\subsection{Kompleksitas Audit}

Menurut Sanusi dan Iskandar (2007:38), kompleksitas audit adalah tugas yang tidak terstruktur, membingungkan dan sulit dikerjakan.

Menurut Ruky (2001:60), kompleksitas audit merupakan tingkat kesulitan tugas dan variasi pekerjaan terutama dalam bentuk 
tekanan terhadap mental dan psikis orang yang melakukan pekerjaan.

Menurut Prasita dan Adi (2007:5), ada dua indikator yang dapat digunakan untuk mengukur kompleksitas audit yaitu :

1. Kesulitan tugas

2. Struktur tugas

\subsection{Integritas Auditor}

Menurut Mulyadi (2002:56), integritas adalah kualitas yang mendasari kepercayaan publik dan merupakan suatu patokan (benchmark) bagi para anggota dalam menguji semua keputusan yang diambilnya.

Menurut Priansa (2016:288), integritas adalah komitmen, janji yang harus ditepati, untuk menunaikan darma hingga tuntas, tidak pura-pura lupa pada tugas atau ingkar pada tanggung jawab.

Menurut Sukriah, dkk (2009), ada empat indikator yang mempengaruhi integritas auditor yaitu :

1. Kejujuran auditor

2. Keberanian auditor

3. Sikap bijaksana auditor

4. Tanggung jawab auditor

\subsection{Kualitas Audit}

Menurut De Angelo dalam Fitrawansyah (2014:49), kualitas audit adalah probabilitas untuk seorang auditor agar dapat menemukan dan melaporkan adanya suatu penyelewengan dalam sistem akuntansi klien.

Menurut Lee, Liu, dan Wang dalam Ardianingsih (2018:23), kualitas audit adalah probabilitas bahwa seorang auditor tidak akan melaporkan laporan hasil audit dengan opini wajar tanpa pengecualian untuk laporan keuangan yang mengandung salah saji material.

Menurut Sukriah (2009), ada dua indikator yang dapat mempengaruhi kualitas audit yaitu :

1. Kesesuaian pemeriksaan dengan standar audit

2. Kualitas laporan hasil pemeriksaan

\subsection{Pengaruh Due Professional Care Terhadap Kualitas Audit Menurut Pancawati} Hardiningsih dan Pachmawati Meita Oktaviani (2012), bahwa setiap auditor selalu melakukan review secara kritis pada setiap tingkat supervise terhadap pelaksanaan audit dan terhadap setiap pertimbangan audit maka auditor akan selalu menjaga kualitas hasil auditnya.

Menurut Singgih dan Bawono (2010:10), setiap auditor harus mampu menjaga sikap skeptis profesional selama proses melaksanakan pemeriksaannya, karena saat auditor sudah tidak mampu lagi mempertahankan sikap skeptis profesionalnya, maka laporan keuangan yang diaudit tidak dapat dipercaya lagi, dan memungkinkan adanya litigasi paksa audit.

Menurut Mulyadi (2002:27), kecermatan dan keseksamaan meletakkan tanggung jawab kepada setiap auditor dalam organisasi kantor akuntan publik untuk mengamati standar auditing yang berlaku.

H1: $\begin{aligned} & \text { Due Professional Care } \\ & \text { berpengaruh terhadap } \\ & \text { Kualitas Audit }\end{aligned}$




\subsection{Pengaruh Kompleksitas Audit Terhadap Kualitas Audit}

Menurut Restuningdiah dan Indrianto (2000), menyatakan bahwa peningkatan kompleksitas audit dalam suatu tugas atau sistem, akan menurunkan tingkat keberhasilan tugas tersebut dan kualitas auditnya.

Menurut Prasita dan Adi (2007:16), bahwa kompleksitas audit yang muncul karena semakin tingginya variabilitas dan ambiguitas tugas pengauditan, menjadi penyebab turunnya kualitas audit.

Menurut Boynton (2002:54), semakin meningkatnya tingkat kompleksitas, maka risiko salah interpretasi dan risiko munculnya kesalahan yang tidak disengaja juga akan ikut meningkat. Karena para pengguna juga akan merasa semakin sulit, atau bahkan mustahil untuk mengevaluasi sendiri mutu laporan keuangan tersebut, maka mereka mengandalkan auditor yangindependen untuk menilai mutu informasi yang dimuat dalam laporan keuangan tersebut.

H2: Kompleksitas

Audit berpengaruh terhadap Kualitas Audit

\subsection{Pengaruh Integritas Auditor Terhadap Kualitas Audit \\ Menurut \\ Pusdiklatwas (2008:58), dengan dimilikinya} integritas yang tinggi, maka auditor dapat meningkatkan kualitas hasil pemeriksaannya.

Menurut Mulyadi (2002:56), integritas dapat menerima kesalahan yang tidak disengaja dan perbedaan pendapat yang jujur, tetapi tidak dapat menerima kecurangan ataupun peniadaan prinsip.
Menurut Badjuri (2011:2), untuk memelihara dan meningkatkan kepercayaan publik, setiap auditor harus mampu memenuhi tanggung jawab profesionalnya dengan integritas setinggi mungkin. Integritas merupakan suatu karakter yang mendasari timbulnya pengakuan professional.

H3: Integritas Auditor berpengaruh terhadap Kualitas Audit

\section{Metode Penelitian}

\subsection{Pendekatan Penelitian}

Pendekatan penelitian yang digunakan dalam penelitian ini adalah metode penelitan kuantitatif. Menurut Sugiyono (2016:8), metode penelitian kuantitatif merupakan suatu metode penelitian yang berlandaskan pada filsafat positivisme, yang digunakan untuk meneliti pada populasi atau sampel tertentu, pengumpulan data menggunakan instrumen penelitian, analisis data bersifat kuantitatif/statistik, dengan tujuan untuk menguji hipotesis yang telah ditetapkan.

\subsection{Populasi dan Sampel}

Menurut Sugiyono (2016:80), populasi merupakan wilayah generalisasi yang terdiri atas : obyek/subyek yang mempunyai kualitas dan karakteristik tertentu yang ditetapkan oleh si peneliti untuk dipelajari dan kemudian ditarik kesimpulannya.

Menurut Sugiyono (2016:81), sampel merupakan bagian dari jumlah dan karakteristik yang dimiliki oleh populasi tersebut. Teknik pengambilan sampel yang digunakan dalam penelitian ini adalah menggunakan teknik 


$\begin{array}{lcr}\text { sampling } & \text { purposive. } & \text { Menurut } \\ \text { Sugiyono } & \text { (2016:85), } & \text { sampling } \\ \text { purposive } & \text { merupakan } & \text { teknik } \\ \text { penentuan } & \text { sampel } & \text { dengan } \\ \text { pertimbangan tertentu. } & \end{array}$

Jumlah populasi di kota Medan ada 8 Kantor Akuntan Publik dengan jumlah 90 auditor yang terdiri dari 60 auditor yang dijadikan sampel penelitian.

\subsection{Teknik Pengumpulan Data}

Adapun teknik pengumpulan data yang digunakandalam penelitian ini yaitu melalui kuesioner atau angket.

\subsection{Jenis dan Sumber Data Penelitian}

Jenis data yang digunakan untuk penelitian ini adalah data primer. Jenis data yang diperoleh dari auditor Kantor Akuntan Publik adalah data primer di dalam penelitian ini berupa hasil pengisian kuesioner yang dibagikan kepada responden.

\section{HASIL PENELITIAN DAN}

Tabel IV.1

Statistik Deskriptif

Descriptive Statistics

\begin{tabular}{|l|r|r|r|r|r|}
\hline & N & Minimum & Maximum & Mean & $\begin{array}{c}\text { Std. } \\
\text { Deviation }\end{array}$ \\
\hline Due Professional & 60 & 38 & 47 & 41.78 & 2.059 \\
Care & & & & & \\
Kompleksitas Audit & 60 & 13 & 19 & 16.47 & 1.186 \\
Integritas Auditor & 60 & 28 & 39 & 33.45 & 1.995 \\
Kualitas Audit & 60 & 12 & 20 & 16.50 & 1.652 \\
Valid N (listwise) & 60 & & & & \\
\hline
\end{tabular}

PEMBAHASAN

\subsection{Statistik Deskriptif}

Berdasarkan hasil analisis deskriptif statistik akan ditampilkan karakteristik sampel yang digunakan dalam penelitian ini meliputi : jumlah sampel $(\mathrm{N})$, rata-rata (mean), nilai maksimum, nilai minimum serta standar deviasi $(\sigma)$ untuk masingmasing variabel. Hasil analisis deskriptif dapat dilihat pada tabel IV.1 berikut ini :

\subsection{Uji Normalitas}

Uji normalitas bertujuan untuk menguji apakah dalam model regresi, variabel penggangu atau residual memiliki distribusi normal atau tidak, antara variabel dependen dengan variabel independen.

\section{A. Analisis Grafik}

1. Histogram

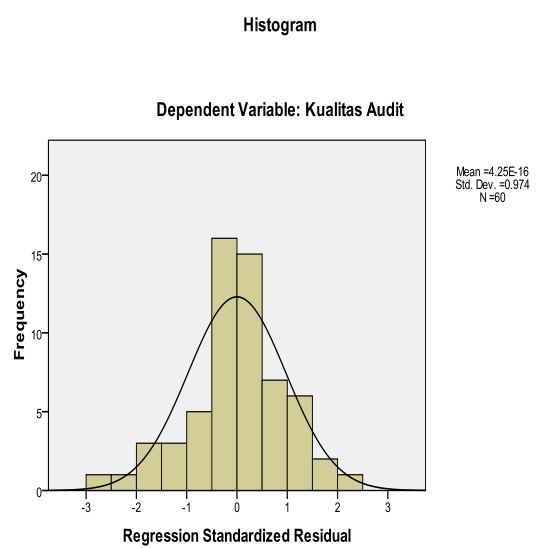

Gambar IV.1

Sumber : Hasil Pengolahan Data SPSS, 2019

Dilihat dari gambar diagram histogram diatas terlihat bahwa garis pada daftar grafik menunjukkan garis mengikuti diagram batang dan tidak menceng kekiri atau kekanan, hal ini menunjukkan bahwa model regresi layak dan berdistribusi normal.

\section{Probability Plot}


Normal P-P Plot of Regression Standardized Residual

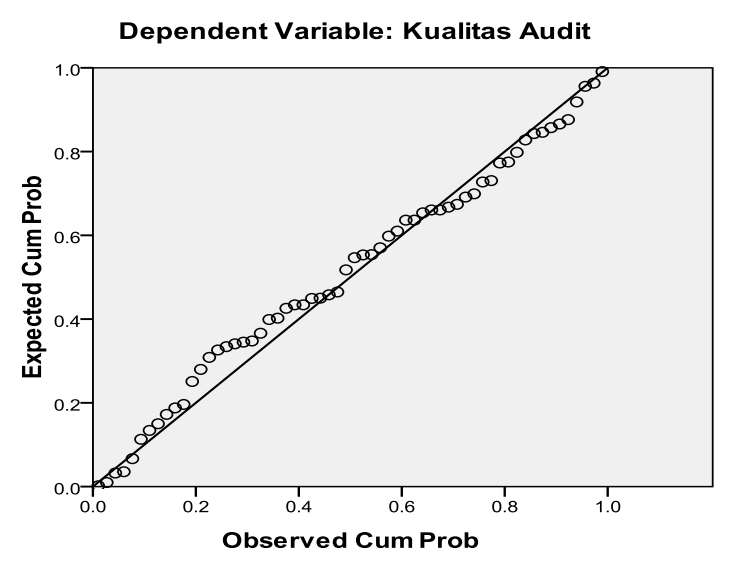

Gambar IV.2

Grafik Normal Probability Plot Sumber : Hasil Pengolahan Data SPSS, 2019

Dilihat dari grafik normalitas diatas (Normal P-Plot of Regression Standardized Residual) memiliki kemiringan kurva yang cenderung seimbang, baik pada sisi kiri dan kanan serta tampilan grafik normal plot memiliki titik-titik yang menyebar disekitar garis diagonal dan penyebarannya searah mengikuti garis diagonal. Dengan demikian, model regresi memenuhi asumsi normalitas.

Sumber : Hasil Pemeriksaan Data SPSS, 2019

B. Uji Statistik dengan nonparametik Kolmogorov-Smirnov $(K-S)$

Tabel IV.2

One-Sample Kolmogorov-Smirnov Test

\begin{tabular}{|c|c|c|}
\hline & & $\begin{array}{c}\text { Unstandardized } \\
\text { Residual }\end{array}$ \\
\hline \multicolumn{2}{|l|}{$\mathbf{N}$} & 60 \\
\hline Normal & Mean & .0000000 \\
\hline Parameters ${ }^{\mathrm{a}, \mathrm{b}}$ & Std. Deviation & 1.43586867 \\
\hline \multirow{3}{*}{$\begin{array}{l}\text { Most Extreme } \\
\text { Differences }\end{array}$} & Absolute & .089 \\
\hline & Positive & .051 \\
\hline & Negative & -.089 \\
\hline \multicolumn{2}{|c|}{ Kolmogorov-Smirnov Z } & .686 \\
\hline \multicolumn{2}{|c|}{ Asymp. Sig. (2-tailed) } & .734 \\
\hline
\end{tabular}

Berdasarkan Tabel IV.2, nilai Kolmogorov-Smirnov adalah 0,686 dan signifikan pada 0,734 dimana nilai signifikansinya di atas 0,05 $(0,734>0,05)$. Dengan demikian, dapat dikatakan bahwa data residual berdistribusi normal.

\subsection{Uji Multikolonieritas}

Uji multikolonieritas bertujuan untuk menguji apakah dalam model regresi ditemukan adanya korelasi antar variabel bebas (independen). Untuk mendeteksi ada atau tidaknya multikoloniertias di dalam model regresi dapat dilakukan dengan melihat Tolerance dan Variance Inflaction Factor (VIF).

Tabel IV.3

Hasil Uji Multikolonieritas

Coefficients $^{\text {a }}$

\begin{tabular}{|c|c|c|c|}
\hline \multirow{2}{*}{\multicolumn{2}{|c|}{ Model }} & \multicolumn{2}{|c|}{ Collinearity Statistics } \\
\hline & & Tolerance & VIF \\
\hline \multirow[t]{4}{*}{1} & (Constant) & & \\
\hline & Due Professional Care & .923 & 1.083 \\
\hline & Kompleksitas Audit & .937 & 1.068 \\
\hline & Integritas Auditor & .985 & 1.015 \\
\hline
\end{tabular}

Berdasarkan tabel IV.3, nilai Tolerance untuk variabel Due Professional Care sebesar 0,923, untuk variabel Kompleksitas Audit sebesar 0,937, dan untuk variabel Integritas Auditor sebesar 9,85. Nilai-nilai tolerance tersebut $>0,10$. Nilai Variance Inflaction Factor (VIF) untuk variabel Due Professional Care sebesar 1,083, untuk variabel Kompleksitas Audit sebesar 1,068, dan untuk variabel Integritas Auditor sebesar 1,015. Nilai-nilai Variance Inflaction 
Factor (VIF) < 10. Dengan demikian, persamaan regresi tidal terjadi multikolonieritas.

\subsection{Uji Heteroskedastisitas}

Uji heteroskedastisitas bertujua untuk menguji apakah dalam mode regresi terjadi adanya ketidaksamaa varians dari residual

\begin{tabular}{|c|c|c|c|c|c|c|}
\hline & & \multicolumn{2}{|c|}{$\begin{array}{c}\text { Unstandardized } \\
\text { Coefficients }\end{array}$} & \multirow{2}{*}{\begin{tabular}{c|}
$\begin{array}{c}\text { Standardized } \\
\text { Coefficients }\end{array}$ \\
Beta
\end{tabular}} & \multirow[b]{2}{*}{$\mathrm{t}$} & \multirow[b]{2}{*}{ Sig. } \\
\hline \multicolumn{2}{|c|}{ Model } & B & Std. Error & & & \\
\hline 1 & (Constant) & -3.279 & 3.116 & & -1.052 & .297 \\
\hline & $\begin{array}{l}\text { Due Professional } \\
\text { Care }\end{array}$ & .075 & .059 & .166 & 1.268 & .210 \\
\hline & Kompleksitas Audit & .192 & .102 & .245 & 1.886 & .064 \\
\hline & Integritas Auditor & -.058 & .059 & -.123 & -.975 & .334 \\
\hline
\end{tabular}

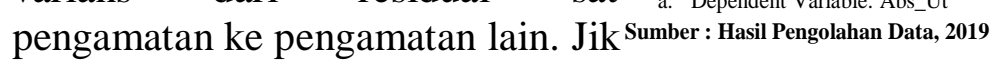
varians dari residual satu pengamatan ke pengamatan lain tetap, maka disebut sebagai homoskedastisitas dan jika berbeda disebut sebagai heteroskedastisitas. Untuk mendeteksi ada tidaknya heteroskedastisitas di dalam model regresi dapat dilakukan dengan menganalisis penyebaran titik-titik pada scatterplot dan uji glejser.

\section{Scatterplot}

Scatterplot

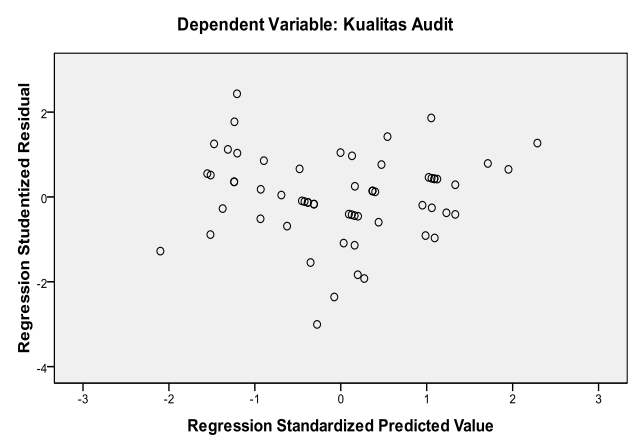

Gambar IV.3

Sumber : Hasil Pengolahan Data SPSS, 2019

Berdasarkan gambar IV.3, dapat dilihat bahwa titik-titik pada scatterplot tidak ada pola yang jelas dan menyebar diatas dan dibawah angka 0 pada sumbu Y. Dengan demikian, model regresi tidak terjadi heteroskedastisitas.

\section{Uji Glejser}

Berdasarkan tabel IV.4, hasil uji glejservariabel Due Professional Care (X1) dimana nilai signifikan sebesar 0,210 dengan syarat nilai signifikan diatas $0,05 \quad(0,210>$ 0,05), variabel Kompleksitas Audit (X2) dimana nilai signifikan sebesar 0,064 dengan syarat nilai signifikan diatas $0,05(0,064>0,05)$, dan variabel Integritas Auditor (X3) dimana nilai signifikan sebesar 0,334 dengan syarat nilai signifikan diatas $0,05(0,334>0,05)$. Dengan demikian, dapat dikatakan model regresi tidak terjadi heteroskedastisitas.

\subsection{Model Penelitian}

Tabel IV.5 Hasil Persamaan Regresi

Coefficients $^{\mathrm{a}}$

\begin{tabular}{|c|c|c|c|c|c|c|}
\hline \multirow{2}{*}{\multicolumn{2}{|c|}{ Model }} & \multicolumn{2}{|c|}{$\begin{array}{c}\text { Unstandardized } \\
\text { Coefficients }\end{array}$} & \multirow{2}{*}{$\begin{array}{c}\begin{array}{c}\text { Standardized } \\
\text { Coefficients }\end{array} \\
\text { Beta }\end{array}$} & \multirow[b]{2}{*}{$\mathrm{T}$} & \multirow[b]{2}{*}{ Sig. } \\
\hline & & B & Std. Error & & & \\
\hline \multirow[t]{4}{*}{1} & (Constant) & 5.863 & 5.120 & & 1.145 & .257 \\
\hline & Due Professional Care & .253 & .097 & .315 & 2.607 & .012 \\
\hline & Kompleksitas Audit & -.449 & .167 & -.322 & -2.683 & .010 \\
\hline & Integritas Auditor & .223 & .097 & .269 & 2.302 & .025 \\
\hline
\end{tabular}

a. Dependent Variable: Kualitas Audit

Sumber : Hasil Pengolahan Data, 2019

Berdasarkan tabel IV.5 persamaan regresi linear berganda dalam penelitian ini adalah sebagai berikut : 
Kualitas Audit = 5,863 + 0,253 Due

Professional Care - 0,449

Kompleksitas Auditor

+ 0,223 Integritas Auditor + e

Pengujian hipotesis menyatakan

bahwa Due Professional Care, Kompleksitas Audit, dan Integritas Auditor berpengaruh terhadap Kualitas Audit pada Kantor Akuntan Publik di Medan, dari penjelasan tersebut dapat dijelaskan bahwa :

1. Konstanta sebesar 5,863 menyatakan bahwa jika due Tabel IV.6

Hasil Koefisien Determinasi

Model Summary $^{\text {b }}$

\begin{tabular}{|l|r|r|r|r|}
\hline Model & \multicolumn{1}{|c|}{$\mathrm{R}$} & R Square & \multicolumn{1}{c|}{$\begin{array}{c}\text { Adjusted R } \\
\text { Square }\end{array}$} & $\begin{array}{c}\text { Std. Error of the } \\
\text { Estimate }\end{array}$ \\
\hline 1 & $.494^{\mathrm{a}}$ & .244 & .204 & 1.474 \\
\hline
\end{tabular}

a. Predictors: (Constant), Integritas Auditor, Kompleksitas Audit, Due Professional Care

Sumber : Hasil Pengolahan Data, 2019

professional care, kompleksitas audit, dan integritas auditor bernilai 0 atau konstan maka Kualitas Audit sebesar 5,863 satuan.

2. Koefisien regresi due professional care sebesar 0,253 dan bernilai positif, hal ini menyatakan bahwa setiap kenaikan due professional care 1 satuan akan meningkatkan kualitas audit sebesar 0,253 satuan dengan anggapan variabel lainnya tetap.

3. Koefisien

regresi

kompleksitas auditsebesar 0,449 dan bernilai negatif, hal ini menyatakan bahwa setiap kenaikan kompleksitas audit1 satuan akan menyebabkan penurunan kualitas audit sebesar 0,449 satuan dengan anggapan variabel lainnya tetap.

4. Koefisien regresi integritas auditor sebesar 0,223 dan bernilai positif, hal ini menyatakan bahwa setiap kenaikan integritas auditor1 satuan akan meningkatkan kualitas audit sebesar 0,223 satuan dengan anggapan variabel lainnya tetap.

\subsection{Koefisien Hipotesis (Uji R $\mathbf{R}^{2}$ ) \\ Koefisien}

\section{Determinasi} $\begin{array}{llr}\text { merupakan } & \text { besaran } & \text { yang } \\ \text { menunjukkan } & \text { besarnya } & \text { variasi }\end{array}$ determinasi variabel dependen (kualitas audit) yang dapat dijelaskan oleh variabel independen (due professional care, kompleksitas audit, dan integritas auditor).

Berdasarkan tabel IV.6, diperoleh bahwa nilai koefisien determinasi hipotesis adalah 0,204. Hal ini menunjukkan bahwa 20,4\% variasi kualitas audit (Y) dapat dijelaskan oleh variasi variabel due professional care (X1), kompleksitas audit (X2), dan integritas auditor (X3). Sisanya $79,6 \%$ merupakan variabel lain di luar dari penelitian ini.

\subsection{Pengujian Hipotesis Secara Simultan (Uji F)}

Uji simultan atau uji F dilakukan untuk mengetahui tingkat positif dan signifikansi dari variabel-variabel due professional, kompleksitas audit, dan integritas auditor terhadap variabel kualitas audit dapat dilihat pada tabel IV.7. 


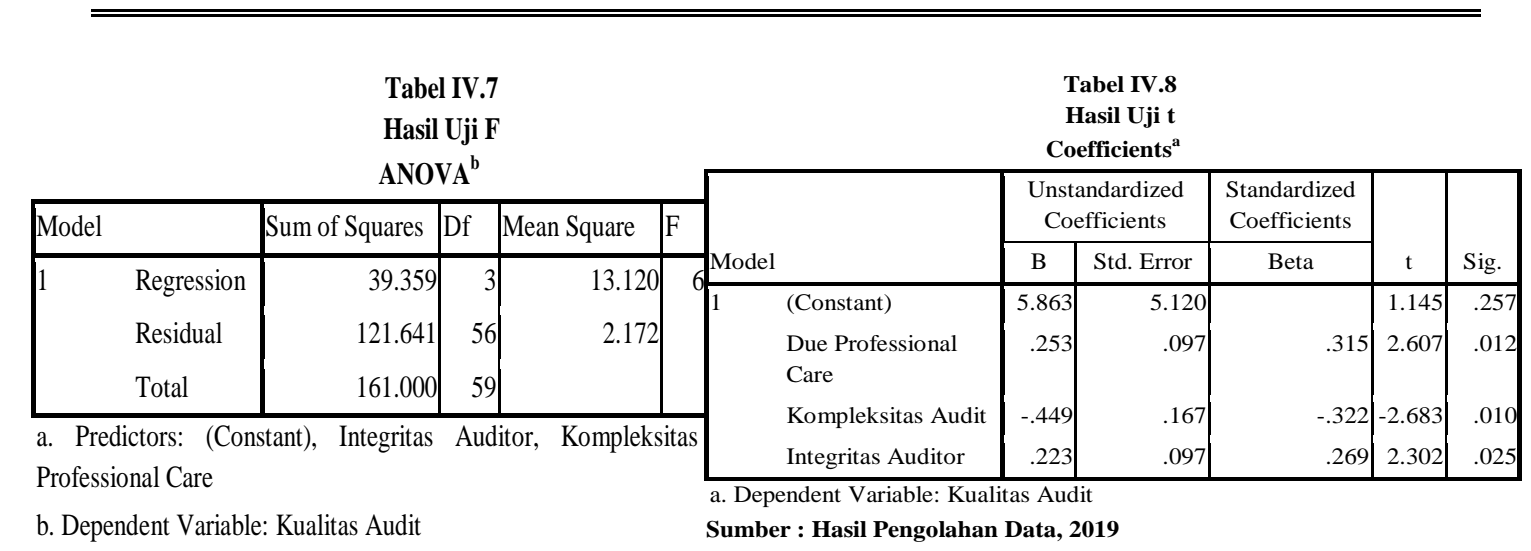

Sumber : Hasil Pengolahan Data, 2019

Berdasarkan hasil uji $\mathrm{F}$ pada tabel IV.7, nilai $F_{\text {hitung }}$ sebesar 6,040. Pada derajat bebas $1\left(\mathrm{df}_{1}\right)=\mathrm{k}-1=4-$ $1=3$, derajat bebas $2\left(\mathrm{df}_{2}\right)=\mathrm{n}-\mathrm{k}=$ $60-4=56$, dimana $\mathrm{n}=$ jumlah sampel, $\mathrm{k}=$ jumlah variabel, maka nilai $F_{\text {tabel }}$ pada taraf kepercayaan signifikansi 0,05 adalah 2,77, dengan demikian dari hasil perhitungan SPSS diperoleh nilai $F_{\text {hitung }}>F_{\text {tabel }}=$ $6,040>2,77$ dengan tingkat signifikansi 0,001. Dikarenakan $\mathrm{F}_{\text {hitung }}>\mathrm{F}_{\text {tabel }}=6,040>2,77$ dan probabilitas signifikansi $0,001<$ 0,05 , maka $\mathrm{H}_{1}$ diterima artinya due professional care, kompleksitas audit, dan integritas auditor secara simultan berpengaruh signifikan terhadap kualitas audit pada Kantor Akuntan Publik (KAP) di Medan.

\subsection{Pengujian Hipotesis Secara Parsial (Uji t)}

Pengujian hipotesis secara parsial dilakukan untuk mengetahui adanya pengaruh satu variabel independen (due professional care, kompleksitas audit, dan integritas auditor) secara individual dalam menerangkan variasi variabel dependen (kualitas audit).
Berdasarkan hasil uji $\mathrm{t}$ pada tabel IV.8, nilai $\mathrm{t}_{\text {tabel }}$ untuk $\mathrm{df}=\mathrm{n}-\mathrm{k}=$ 60-4 = 56 dan signifikansi 0,05 pada uji signifikansi 2 arah adalah sebesar 2,00324. Dengan demikian hasil dari uji $\mathrm{t}$ dapat dijelaskan sebagai berikut :

1. Hasil perhitungan uji $\mathrm{t}$ secara parsial diperoleh nilai $t_{\text {hitung }} d u e$ professional care sebesar 2,607 dengan nilai signifikan sebesar 0,012. Nilai $t_{\text {hitung }}>t_{\text {tabel }}$ atau $2,607>2,00324$ maka $\mathrm{H}_{1}$ diterima artinya due professional care secara parsial berpengaruh positif dan signifikan terhadap kualitas audit pada Kantor Akuntan Publik (KAP) di Medan.

2. Hasil perhitungan uji t secara parsial diperoleh nilai $t_{\text {hitung }}$ kompleksitas audit sebesar 2,683 dengan nilai signifikan sebesar 0,010. Nilai - $t_{\text {hitung }}<-$ $t_{\text {tabel }}$ atau $-2,683<-2,00324$ maka $\mathrm{H}_{1}$ diterima artinya kompleksitas audit secara parsial berpengaruh negatif dan signifikan terhadap kualitas audit pada Kantor Akuntan Publik (KAP) di Medan.

3. Hasil perhitungan uji t secara parsial diperoleh nilai $t_{\text {hitung }}$ integritas auditor sebesar 2,302 dengan nilai signifikan sebesar 0,025 . Nilai $t_{\text {hitung }}>t_{\text {tabel }}$ atau $2,302>2,00324$ maka $\mathrm{H}_{1}$ 
diterima artinya integritas auditor secara parsial berpengaruh positif dan signifikan terhadap kualitas audit pada Kantor Akuntan Publik (KAP) di Medan.

\section{KESIMPULAN DAN SARAN}

\subsection{Kesimpulan}

Berdasarkan hasil analisis dan pembahasan yang telah diuraikan pada bab sebelumnya, maka peneliti menarik kesimpulan sebagai berikut :

1. Due professional care berpengaruh positif terhadap kualitas audit pada Kantor Akuntan Publik (KAP) di Medan. Hasil ini menunjukkan bahwa auditor selalu melakukan review secara kritis pada setiap tingkat supervise dan selalu menerapkan sikap skeptis dalam dirinya. Dengan demikian, semakin tinggi due professional care yang dimiliki oleh seorang auditor, maka akan semakin baik pula kualitas audit yang dihasilkan.

2. Kompleksitas audit berpengaruh negatif terhadap kualitas audit pada Kantor Akuntan Publik (KAP) di Medan. Hasil ini menunjukkan bahwa auditor harus siap dalam menghadapi berbagai kesulitan tugas dan harus mampu menyelesaikan tugas yang diberikan kepadanya walaupun tugas yang dikerjakan sulit. Auditor juga harus mampu mempertahankan objektifitas dari hasil pemeriksaannya. Dengan demikian, semakin tinggi tingkat kompleksitas audit dalam suatu tugas yang dikerjakan, maka semakin rendah kualitas audit yang dihasilkan.
3. Integritas auditor berpengaruh positif terhadap kualitas audit pada Kantor Akuntan Publik (KAP) di Medan. Hasil ini menunjukkan bahwa auditor harus mampu menjaga sikap integritas dalam dirinya, karena jika seorang auditor tidak dapat menerapkan integritas dalam dirinya maka hasil dari laporan audit tersebut tidak dapat di pertanggungjawabkan. Dengan demikian, semakin tinggi integritas yang dimiliki seorang auditor, maka semakin baik kualitas hasil auditnya.

4. Hasil uji $\mathrm{F}$ menunjukkan bahwa due professional care, kompleksitas audit, dan integritas auditor berpengaruh signifikan terhadap kualitas audit pada Kantor Akuntan Publik (KAP) di Medan. Dengan demikian semakin tinggi due professional care dan integritas auditor maka semakin tinggi kualitas auditnya dan semakin tinggi kompleksitas audit maka semakin rendah kualitas auditnya.

5. Hasil uji koefisien determinasi hipotesis dengan Adjuster $\mathrm{R}^{2}$ sebesar 0,204. Hal ini menunjukkan bahwa 20,4\% variasi kualitas audit (Y) dapat dijelaskan oleh variasi variabel due professional care (X1), kompleksitas audit (X2), dan integritas auditor (X3). Sisanya $79,6 \%$ merupakan variabel lain di luar dari penelitian ini.

\subsection{Saran}

Saran-saran yang dapat peneliti berikan berdasarkan hasil penelitian ini adalah sebagai berikut : 
1. Bagi Kantor Akuntan Publik, diharapkan dapat menjaga dan meningkatkan kualitas auditnya, auditor tetap harus memiliki kehati-hatian dan kecermatan dalam mengaudit agar laporan yang dihasilkan bebas dari salah saji materil baik secara kekeliruan maupun kecurangan, auditor tetap harus siap dalam menghadapi berbagai kesulitan tugasnya, karena auditor tidak hanya harus bekerja lebih keras, namun auditor juga memperoleh pengetahuan dan pengalaman dalam menyelesaikan penugasan audit yang diberikan, dan auditor tetap harus menjaga sikap integritas dalam diri seorang auditor untuk tetap jujur dan bertanggung jawab kepada semua tugas yang diberikan.

2. Bagi Peneliti Selanjutnya, disarankan untuk memperluas area penelitian. Hal ini diperlukan untuk meningkatkan akurasi hasil yang akan digunakan di masa mendatang supaya hasil penelitiannya lebih sempurna.

\section{DAFTAR PUSTAKA}

Ardianingsih, Arum. 2018. Audit Laporan Keuangan. Jakarta : PT. Bumi Aksara.

Agustin, Aulia. 2013. "Pengaruh Pengalaman, Independensi, dan Due Professional Care Auditor Terhadap Kualitas Audit Laporan Keuangan
Pemerintah (Studi Empiris pada BPK-RI Perwakilan Provinsi Riau)". Jurnal Akuntansi. Vol. 1, No. 1. Padang.

Badjuri, Achmat. 2011. "FaktorFaktor yang Berpengaruh Terhadap Kualitas Hasil Pemeriksaan Auditor Sektor Publik". Prosiding Seminar Nasional Multi Disiplin Ilmu.

Boynton, William C, et.al. 2002. Modern Auditing. Jilid 1. Edisi 7. Jakarta : Erlangga

Fitrawansyah. 2014. Fraud \& Auditing. Edisi Pertama. Jakarta : Mitra Wacana Media.

Hardiningsih, Pancawati dan Rachmawati Meita Oktaviani. 2012. "Pengaruh Due Professional Care, Etika, dan Tenur Terhadap Kualitas Audit". Fakultas Ekonomi Unisbank Semarang.

Mulyadi. 2002. Auditing. Edisi. 6 . Cetakan ke-I. Jakarta : Salemba Empat.

Prasita, Andin dan Priyo Hari Adi. 2007. "Pengaruh Kompleksitas Audit dan Tekanan Anggaran Waktu Terhadap Kualitas Audit dengan Moderasi Pemahaman Terhadap Sistem Informasi". Jurnal Ekonomi dan Bisnis. Fakultas 
Ekonomi, Universitas Kristen

Satya Wacana.

Priansa, Donni Juni. 2016.

Perencanaan

Pengembangan

SDM.

Cetakan Kedua. Bandung :

Alfabeta.

Pusdiklatwas BPKP. 2008. Etika

Dalam Fraud Audit. Edisi

Kelima.

Rahayu, Siti Kurnia dan Ely Suhayati. 2010. Auditing :

Konsep Dasar dan Pedoman Pemeriksaan Akuntan Publik. Edisi Petama. Cetakan Pertama, Yogyakarta : Graha Ilmu.

Restuningdiah, Nurika dan Nur Indriantoro. 2000. "Pengaruh Partisipasi Terhadap Kepuasan Pemakai Dalam Pengembangan Sistem Informasi Dengan Kompleksitas Tugas, Kompleksitas Sistem, dan Pengaruh Pemakai Sebagai Moderating Variabel". Jurnal Riset Akuntansi Indonesia, Vol. 3, No. 2 : 119-133.

Ruky, Achmad S. 2001. Manajemen Penggajian \& Pengupahan Untuk Karyawan

Perusahaan. Jakarta : PT Gramedia Pustaka Utama.

Sanusi, Z. M. and T. M. Iskandar (2007). Effects Of Goal Orientation and Task Complexity On Audit
Judgment Performance.

Journal Accounting and Financial, Vol 6 (2): 123139.

Singgih, Elisha Muliani dan Icuk Rangga Bawono. 2010. "Pengaruh Independensi, Pengalaman, Due Professional Care dan Akuntabilitas Terhadap Kualitas Audit (Studi Pada Auditor di KAP "Big Four" di Indonesia". Simposium Nasional Akuntansi XIII Purwokerto 2010.

Sugiyono. 2016. Metode Penelitian Kuantitatif, Kualitatif, dan $\boldsymbol{R} \& \boldsymbol{D}$. Edisi Baru. Bandung : Alfabeta.

Sukriah, Ika dan Biana Adha Inapty. 2009. "Pengaruh Pengalaman Kerja, Independensi, Objektivitas, Integritas dan Kompetensi Terhadap Kualitas Hasil Pemeriksaan”.

Tuanakotta, Theodorus M. 2011. Berpikir Kritis dalam Auditing. Jakarta : Salemba Empat.

Yenny. 2012. "Pengaruh Pengalaman Kerja, Independensi, Objektivitas, Integritas, dan Kompetensi Auditor terhadap Kualitas Audit yang Dihasilkan Kantor Akuntan Publik (KAP) " The Big Four" di Indonesia". Jurnal Akuntansi. 